\title{
Design of Web-Based Library System at SMP Kemala Bhayangkari 1 Medan
}

\author{
Tansa Trisna Astono Putri ${ }^{1, *}$ Ressy Dwitias Sari ${ }^{2}$ \\ 1,2PTIK-FT, Universitas Negeri Medan, Indonesia \\ "Corresponding author. Email: tansatrisna@ unimed.ac.id
}

\begin{abstract}
This research is entitled Design of Web-Based Library System at SMP Kemala Bhayangkari 1 Medan. This study aims to design an integrated library system and can facilitate the process of borrowing and returning books. This research method uses a qualitative method with the following steps: analyzing the problem by collecting literature studies and previous research, then system design, system implementation, and testing. This research will produce Proceedings with international indexes, Copyrights, Journals of national reputation, KI (Intellectual Property), and Library System Products that will be used by SMP Kemala Bhayangkari 1 Medan.
\end{abstract}

Keywords: Web-based Library, SMP, Design.

\section{INTRODUCTION}

Education is one of the pillars to support the progress of a nation. The teaching and learning process is a very important process in the development of the world of education. To support the teaching and learning process, good reading references are needed in the form of books, dictionaries, magazines, and other reading sources.

A library is not just a building or room that only contains books [1]. Library facilities are built to store collections of books or reading resources. The collection is updated to keep up with the development of science. Likewise in SMP Kemala Bhayangkari 1 Medan. The library at SMP Kemala Bhayangkari 1 Medan has a library manager and has a large collection of books for SMP standards. And the students are required to become members of the school library.

However, the current service process is still conventional. There are several obstacles, namely the length of time looking for the book you are looking for, the difficulty of the librarian in managing borrowing and returning data because they always have to open records so they are prone to errors, then as time goes by, the officers also have difficulty checking the books that are more and more and no longer need to be used again.

To fulfill good and efficient service to its members, the library of SMP Kemala Bhayangkari 1 Medan requires a system to collect data, process data, store data, review data, and distribute good information, one of which is having high data accuracy. To meet these needs, the effort that must be done by the library is the use of information technology such as computers and other library information system applications in addition to increasing human resources and improving systems. A library that is managed using technology requires library staff to store and track book collections and can compile reports [2].

Based on this background, this research will design a web-based library system. The change in the form of manual library data processing to computer-based data processing is a solution to overcome information delays and difficulties in managing detailed data collections of existing books. The expected result of this research is a library system at SMP Kemala Bhayangkari 1 Medan. The information system is expected to provide convenience for collecting data, processing data, storing data, and reviewing data. This convenience is for the librarian and students of SMP Kemala Bhayangkari 1 Medan in borrowing and returning books. The most important hope is that the library system provides accurate data and helps provide effective and efficient activities in the library of SMP Kemala Bhayangkari 1 Medan. 


\section{METHOD}

This research was conducted at SMP Kemala Bhayangkari 1 Medan. The research was carried out from March to November 2021. The method used in this study is a qualitative method. Qualitative methods are used when it is necessary to collect various views from each stakeholder, in making a program before it is introduced [3]. In general, it can be described in the following framework.

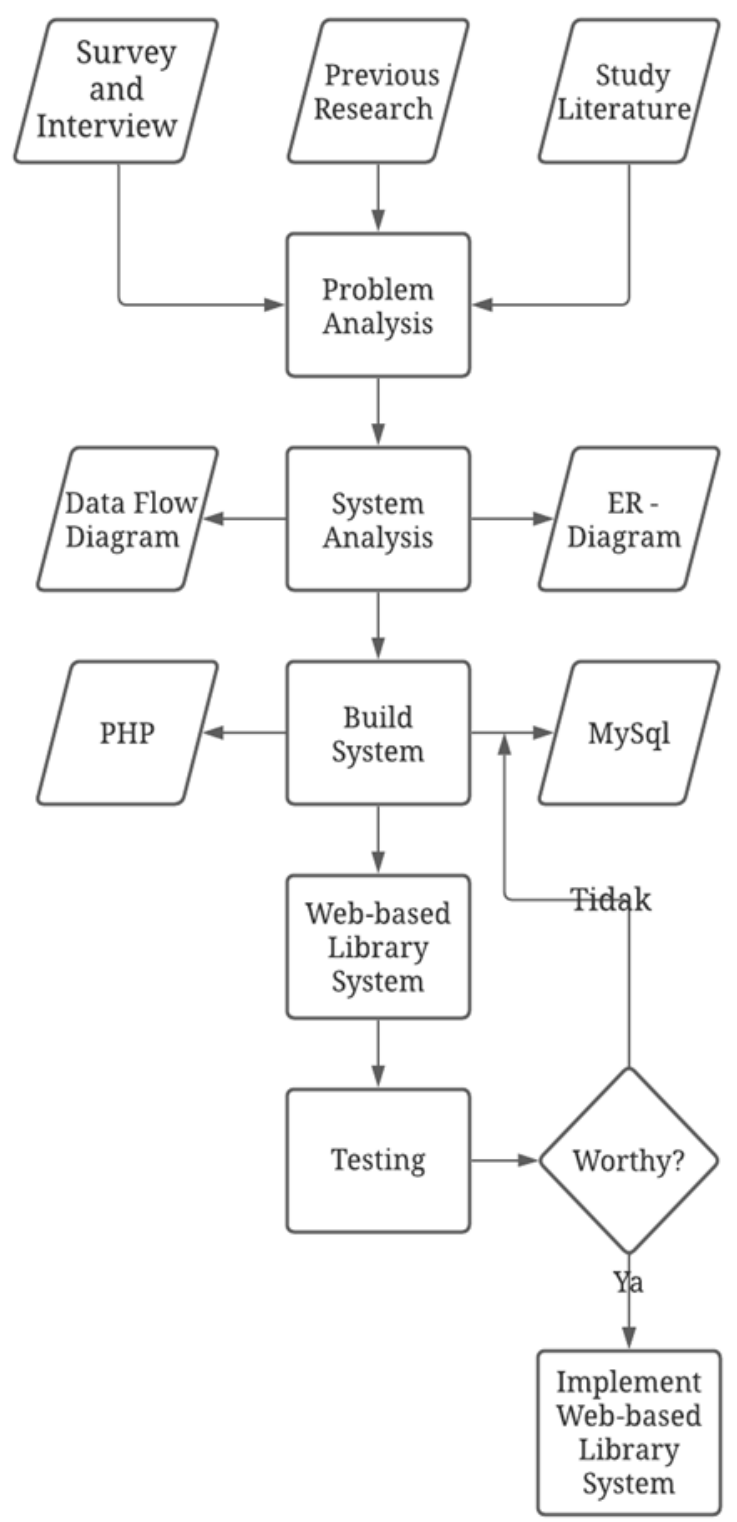

Figure 1 Research framework.

\subsection{Steps}

This research stage describes the steps in recording data and collecting several reports that are needed to be used as guidelines in making this research, namely:

\subsubsection{Preliminary Research}

This preliminary research is the first step in conducting research. The research was conducted by interviewing the principal of SMP Kemala Bhayangkari 1 Medan. Aims to find out the problems and obstacles experienced in the process of borrowing and returning books without using a system. As well as interviewing the librarian who recorded data for borrowing and returning books, to obtain information on the required data [4].

\subsubsection{Data Collection}

In this study, the data taken is external data. This data collection is done by interviewing parties or people who are competent in the process of borrowing and returning books [5]. This data is taken and collected to determine the information needs that must be met in the library system.

\subsubsection{Analysis}

In this analysis stage can be done in two stages, among others, as follows:

- Data and Process Analysis

This is done in 2 ways, namely:

- Study Literature, collect and study research and previous research and journals related to web-based library systems [6].

- Observation, by going directly to the field to meet the parties involved in completing this research where the information and needs will be obtained as material in the manufacture or design of the system [7].

- System Analysis

At this stage of system analysis, it is carried out to design the Web-based system. Where the program will be made using the PHP and MySQL programming languages.

\subsubsection{Design}

At this stage, collecting facts that support the system design from the results of interviews and comparing the results of the research with those in the guidebook, at this stage the researcher uses UML as a tool in explaining the flow of program analysis, namely:

\section{- Data Flow Diagrams}

This diagram shows a method for designing a system that is oriented to the flow of data that moves in a system later. Generally, DFD uses 4 symbols to offer a graphical illustration of data flow through a procedure, those symbols represent: the process, data flow, an external entity, and the data store [8].

\section{- ER-Diagram}

This diagram shows a method for compiling a database in order to describe data that has a relationship with the database to be designed. ER Diagram consists of 
entities, attributes, and relationships. The entityrelationship model is the highest level in database design [9].

\subsubsection{Implementation}

In this subchapter, the researcher will discuss the programming language that will be used. Researchers will use the PHP programming language with a MySQL database because this programming language is considered suitable for making web-based programs and easy to use.

\subsubsection{Testing}

The results of the tests carried out previously will work in this process using the cross-validation method to get the best results [10]. The system built must be able to record data for borrowing and returning books computerized or via online. And after the coding process is complete, a testing process will be carried out on the resulting application to find out whether the designed application is running correctly and in accordance with the design carried out.

\section{RESULT AND DISCUSSION}

The system application is a result of this study. The following are the aspects that need to be fulfilled as a complete system.

Table 1. Table for Admin Script.

\begin{tabular}{|c|c|c|}
\hline Script Name & Component & Specific Action \\
\hline \multirow[t]{8}{*}{ Website Maintenance } & Login & $\begin{array}{ll}- & \text { Input username and password } \\
- & \text { Log in administrator web page }\end{array}$ \\
\hline & Manage User & $\begin{array}{cc}- & \text { Check user registered } \\
- & \text { Edit user data } \\
- & \text { Insert user registered } \\
& \text { Delete user data }\end{array}$ \\
\hline & Manage Book Location & $\begin{array}{cc}- & \text { Check Book Location } \\
- & \text { Edit Book Location } \\
- & \text { Insert Book Location } \\
- & \text { Delete Location }\end{array}$ \\
\hline & Manage Category & $\begin{array}{lc}- & \text { Check category } \\
- & \text { Edit category } \\
- & \text { Insert category } \\
- & \text { Delete category }\end{array}$ \\
\hline & Manage Book & $\begin{array}{cc}- & \text { Check data of books } \\
- & \text { Edit data of book } \\
- & \text { Insert data of book } \\
- & \text { Delete data of book }\end{array}$ \\
\hline & Manage Loan & $\begin{array}{lc}- & \text { Check loan data } \\
- & \text { Edit loan data } \\
- & \text { Insert loan data } \\
- & \text { Delete loan data }\end{array}$ \\
\hline & Manage Return & $\begin{array}{l}\text { Check return data } \\
\text { Edit return data } \\
\text { Insert return data } \\
\text { Delete return data }\end{array}$ \\
\hline & Manage Fine & $\begin{array}{lc}- & \text { Check fine data } \\
- & \text { Edit fine data } \\
- & \text { Insert fine data } \\
- & \text { Delete fine data }\end{array}$ \\
\hline
\end{tabular}


Table 2. Table for User Script.

\begin{tabular}{|c|c|c|}
\hline Script Name & Component & Specific Action \\
\hline \multirow[t]{4}{*}{ Website Maintenance } & Login & $\begin{array}{ll}- & \text { Input username and password } \\
- & \text { Log in to the user web page }\end{array}$ \\
\hline & Manage Profile & $\begin{array}{ll}- & \text { Check profile data } \\
- & \text { Edit profile data }\end{array}$ \\
\hline & Manage Loan & Check user's loan \\
\hline & Manage Return & Check user's return \\
\hline
\end{tabular}

\section{CONCLUSION}

Based on the research we conducted, we could conclude that a web-based library system is a great help for SMP Kemala Bhayangkari 1 Medan. The system that resulted in this research could provide the librarian and students to use the library more effectively and efficiently. The system could support the data that is needed by the librarian and the students. Librarians could gain the loan and return data. The student could also gain the books' information that is supported in the library. Students could also notice their loan and return status.

\section{REFERENCES}

[1] Ivanković, Z., Markoski, B., Berković, I., and Ivetić D. Realization of school library software application SISY 2009 - 7th Int. Symp. on Intelligent Systems and Informatics (Subotica) (New York: IEEE), 2009, pp 187-191 DOI: https://doi.org/10.1109/SISY.2009.5291166

[2] Supriyono, H., Fitriyan, M.R., and Muamaroh, Developing a QR code-based library management system with case study of private school in Surakarta City Indonesia Proc. of the 3rd Int. Conf. on Informatics and Computing (Palembang) (New York: IEEE), 2018, pp 1-6. DOI: https://doi.org/10.1109/IAC.2018.8780424 5

[3] Brown A P Qualitative method and compromise in applied social research Qual. Res., 2010, PP 10229248DOI:

https://doi.org/10.1177/1468794109356743
[4] Jamshed, S. Qualitative research methodinterviewing and observation J. basic clin. pharm. 2014, pp 5-87

[5] Alshenqeeti, H. Interviewing as a data collection method: A critical review Engl. Linguist. Res, 2014, pp. 39-45

[6] French, A.M. Web development life cycle: a new methodology for developing web applications $\mathrm{J}$. Internet Bank. Commer, 2011.

[7] Fry M, Curtis K, Considine J and Shaban R Z Using observation to collect data in emergency research Australas. Emerg. Nurs. J. 2017, 25-30

[8] Chong $\mathrm{H} \mathrm{Y}$ and Diamantopoulos A Integrating advanced technologies to uphold security of payment: Data flow diagram Autom. Constr. 114(March), 2020, pp. 103158 DOI: https://doi.org/10.1016/j.autcon.2020.103158

[9] Ghosh S, Bashar R, Mukherjee P and Chakraborty B Automated generation of e-r diagram from a given text in natural language Proc. - Int. Conf. on Machine Learning and Data Engineering (Sydney) (New York: IEEE), 2018. pp 97-102 DOI: https://doi.org/10.1109/iCMLDE.2018.00026

[10] Putri, T. T. A., Sriadhi, S., Sari, R. D., Rahmadani, R., \& Hutahaean, H. D. (2020). A comparison of classification algorithms for hate speech detection. IOP Conference Series: Materials Science and Engineering, 830(3). DOI: https://doi.org/10.1088/1757-899X/830/3/032006 